\title{
A New Conceptualization of Mega Sport Event Legacy Delivery: Wicked Problems and Critical Realist Solution
}

\section{Authors}

Terri Byers, University of New Brunswick, Fredericton, Canada

Emily Hayday, Loughborough University London, UK

Athanasios (Sakis) Pappous, University of Kent, UK

Key Words: Critical Realism; Wicked Problems; Legacy Delivery; Conceptualization; Mega

Sports Events; Leveraging 


\begin{abstract}
The authors present a new conceptualization of mega sport event legacy delivery, which accounts for the problematic nature of legacy by viewing it as a wicked problem. Research on mega sport event legacy has focused on establishing typologies of legacy, investigating outcomes, and consequences, with limited attention to legacy delivery. The conceptualization of legacy delivery has largely relied on a positive, utopian legacy rhetoric. In contrast, the authors advance the understanding of legacy by proposing a conceptual approach of the legacy delivery process, to enable empirical studies in different contexts to be conducted. Specifically, the authors examine the wicked problem of mega sport event legacy delivery from a Critical Realist perspective, which serves to give meaning and order to this complex process. This conceptualization reveals that legacy delivery is inclusive of deep social structures which underpin different stakeholders' interpretations and interactions, which produce or limit legacy delivery. The role of social, generative structures as causal mechanisms has not been considered as a way to understand legacy delivery previously. Implications for teaching, research, and practice are discussed to demonstrate the value of this new approach. Importantly, this conceptualization focuses on processes rather than outcomes and encourages the identification of unexpected or unanticipated components of legacy delivery beyond the formal policies and plans designed to create or leverage legacy.
\end{abstract}




\section{Introduction}

Mega Sports Event legacy has been subjected to substantial research, which often uses a narrow conceptual lens (Thomson, Cuskelly, Tooney, Kennelly, Burton, \& Fredline, 2018). Mounting evidence challenges the ability of mega sport events to produce sustainable, positive legacies, prompting further research on whether legacy is indeed a fact, or a fairy tale (Brittain, Bocarro, Byers, \& Swart, 2018). Achieving legacy outcomes from a MSE is, however, coveted by politicians, event organizers and powerful stakeholders, as the event in isolation does not justify its cost, in many cases (Brittain et al., 2018). Thomson et al.'s (2018) systematic review identified the importance of legacy planning as a dominant theme in the mega sports event literature, in which engaging key stakeholders and integrated long-term plans were needed to maximise legacy outcomes.

Knowledge regarding legacy planning, delivery, and the barriers associated with realizing legacies is fragmented (Bocarro, Byers, \& Carter, 2018), and there is a need for a holistic model to understand how legacy is delivered (Thomson et al., 2018). In this paper, we theorize such a holistic perpective of legacy and present a new conceptual approach, synthesizing literature on legacy delivery, in particular. As Cunningham (2013) highlighted, all good theories should provide a logical way to understand reality, in this case legacy, and the processes by which it may be produced and delivered. Research suggests that legacy can be achieved through "legacy planning and processes implemented to secure legacies... interactions between delivery stakeholders, risks, process, and outcomes links" (Thomson et al., 2018, p. 9-10). However, we argue that such definitions encourage researchers to, as Weed (2018) commented on sport management scholarship in general, ask the wrong questions and give the wrong answers. Our scholarly approach to legacy has been largely driven by the assumption that legacy is a solution 
to economic, social, cultural, or political challenges. Furthermore, it is often perceived that this 'solution' can be managed, primarily through creating tangible policies, programmes, and structures (Preuss, 2018), whilst considering different stakeholder needs and expectations (Parent, 2016). We seek to challenge this assumption that legacy is solely a solution and reconcile some of the contradictory evidence found in the legacy literature by presenting legacy as a 'wicked problem' (Head \& Alford, 2015; Alford \& Head, 2017).

To develop this new conceptualization of legacy and its delivery, we use three key suggestions by Gilson \& Golberg (2015, p.128) for what constitutes a good conceptual paper, including: (a) thoroughly address "what's new" through proposing new theory, bridging existing theories, link disciplinary perspectives, provide mutli-level insights or broaden the scope of thinking on a topic; (b) provide a relatively brief review of literature (not the focus of the paper) and swiftly move on to tackle one area in need of attention from a particular theoretical lens; and (c) provide figures (nearly universally used in conceptual work) as a visual depiction of the authors' views.

Mega sports event legacy has been defined by Preuss (2007) as "all planned and unplanned, positive and negative, tangible and intangible structures created for and by a sport event that remain longer than the event itself" (p. 211). Yet, the unplanned and negative side of legacy is rarely acknowledged in research on legacy and its delivery (Thomson et al., 2018), perhaps an indication that this definition is insufficient to advance understanding of legacy beyond static categorizations, to a more dynamic and contested process. Legacy delivery is primarily viewed as a top down process, with legacy plans being created and formalized by policy makers and governmental organizations at a national level. These are then fed through relevant regional channels to the individuals and organizations locally who interpret and deliver 
these premeditated plans. Mega events are "ambulatory occasions of a fixed duration that attract a large number of visitors, have a large mediated reach, come with large costs, and have large impacts on the built environment and population" (Muller, 2015, p. 638). While this includes sport and non-sport events, the focus of this paper is on sporting event contexts and Muller's (2015) three size classifications of events as major, mega, and giga-events. In terms of sporting events therefore, we are focused on Olympic games, World Cups, and those sporting events where organizers are pursuing broad transformational agendas. We also acknowledge KassensNoor's (2016) notion that mega event utopia and mega event legacy utopia (idealistic visions of long term consequences and possibilities enabled by these events) exist in the planning stage. This utopia is "dictated" by the desires of mega event owners, such as the International Olympic Committee, regardless of the realities of the host (Kassens-Noor, 2016, p. 42).

Thomson et al. (2018) criticized legacy research for its limited use of established theoretical frameworks and noted that few efforts engage and draw from theories across disciplines. The wicked problem framework has been used extensively within policy research (Head \& Alford, 2015), and in a wide variety of contexts (Kreuter, De Rosa, Howze, \& Baldwin, 2004; Lazarus, 2009; Morner \& Misgeld, 2013); yet, it has had limited application within sport, with some exceptions from Byers (2018) and Sam (2009). Due to the contested and complex nature of sport event legacy (Thomson et al., 2018), and the multiple characteristics of what constitutes mega events (Muller, 2015), the wicked problems framework provides a valuable new conceptual approach, to investigating mega sports event legacy delivery for a range of types/sizes of events. We also consider key strategies for dealing with wicked problems and a range of wickedness (Alford \& Head, 2017) to facilitate thinking on legacy delivery and to understand how legacy develops or is constrained in its development. A critical realist ontology 
underpins our conceptualization as it seeks to uncover why phenomenon does or does not occur, providing added logic and structure to the wicked problem framework.

Critical Realism (Archer, Bhaskar, Collier, Lawson, \& Norrie, 1998; Sayer, 2000; Byers, 2013) encourages examination of the legacy process across multiple layers of reality (Byers, 2018). This provides a logical structure which allows legacy (as a wicked problem) to be explored in a multifaceted and systematic way. As Cunningham (2013) suggested, sport management research needs new theory. We provide a valuable approach, which can be applied to future studies across various mega sports events and legacy types, by providing, as called for by Thomson et al. (2018), a holistic perspective of how legacy is produced. We also contribute to knowledge on mega sports event legacy, by providing a new conceptualization of legacy as problematic, thus challenging the often utopian assumptions which position legacy as a positive way to generate additional (economic, social, and political) outcomes.

Following this introduction, a review of literature reveals gaps in the conceptualization of legacy (what it is, how we know about it) and legacy delivery (as a process) before presenting a new conpetualization, wicked problems, that challenges existing assumptions about legacy. Here, we also begin to identify strategies to manage wicked problems to provide a more holistic view of the legacy delivery process. Next a discussion of the implications of this new perspective to research and practice is presented. Here we argue that by recognizing legacy as problematic rather than merely a solution, and clarify what is new about this perspective for researchers and practitioners, highlights the strengths of our conceptual approach using Gilson and Goldberg's (2015) recommendations for good conceptual papers. Finally, conclusions and implications for future research are provided where we highlight the key contribution of this work to understanding legacy and its delivery. 


\section{Literature Review}

"Legacies are a topic of contentious discourse among event researchers, over definition, measurement, and significance" (Orr \& Jarvis, 2018, p. 345). Grix, Brannagan, Wood, \& Wynne suggest that the popularity of legacy is largely driven by an increasing diverse range of states hosting mega sports events, as well as rising and excessive costs of bidding for and hosting these events. This has resulted in a justificatory discourse around spending on elite sport, in which certain legacies are promoted as appropriate for returns on investment and the continuation of the "perennial and expensive sport cycle" (2017, p. 204). There has been a relentless focus on legacy from the media, academics, goverments, and sport organizations with varying interpretations of its meaning or how to achieve it. We now briefly take stock of this perspective of legacy, demonstrate gaps in our understanding of the concept and its measurement, leading to a counterconceptualization that suggests an innovative, albeit slightly more controversial way to conceive legacy and its delivery.

\subsection{Understanding Legacy}

\subsubsection{Defining legacy: What is it?}

Legacy has been described as a "complex, fluid and contested concept that is likely to be realized differently" across varying contexts, depending on social, economic and political factors and is known to be inherently political (Brownill, Keivani, \& Pereira, 2013, pp. 112-113). Different types of legacy have been identified such as economic (Preuss, 2004), social (Raco, 2004), cultural (Cashman, 1998), environmental (Chappelet, 2008), health (McCartney et al., 2010), sports participation (Veal, Toohey \& Frawley, 2012; Weed et al., 2015), infrastructural (Hiller, 2006; Searle, 2002), political (Grix, 2013), tourism/destination branding (Boukas, Ziakas 
\& Boustras, 2013; Knott, Allen \& Swart, 2012), and security (Giulianotti, 2013). The legacy cube created by Gratton and Preuss (2008) provides one of the most comprehensive explanations of legacy through its identification of multiple legacy classifications, which indicates legacy can be planned, unplanned, positive, negative, tangible, and intangible. Yet, this does not provide insight into the process, how and why that particular legacy outcome (whether positive or negative) was achieved. Several reviews of the legacy literature point to the overwhelming focus on whether legacy exists or not (with only limited knowledge of how legacy was produced, through the methods of measuring the legacy type) (Koenigstorfer, Bocarro, Byers, Edwards, Jones \& Preuss., 2019; Thomson et al., 2018; Bocarro et al., 2018).

Many planned legacies are not realized (Smith, 2014; Brittain et al., 2018) and unplanned, negative or 'shadow' legacies can emerge with no planning efforts and despite preventative measures (Boykoff \& Fussey, 2014). The legacies most often planned for, by a "coalition of beneficiaries" are consistent across regimes and include five overlapping categories: (a) economic, (b) urban regeneration, (c) national pride/feel good factor, (d) increased participation in physical activity and sport, and (e) international prestige/soft power (Grix et al., 2018, p.204). Negative legacies are often ignored (Orr \& Jarvis, 2018), yet evidence suggests they do materialize and represent serious implications for host communities, especially disadvantaged groups, minorities, or those members of society who are not in powerful decision making positions.

Legacies therefore should be regarded as a high risk strategy for justifying exorbitant spending on a sporting mega event and so can be seen as potentially advantageous (if positive legacies are produced) and potentially problematic (if negative, unplanned legacies emerge). For example, a significant amount of legacy research focuses on sport participation legacy, with 
inconclusive evidence for and against the existence and process through which sport

participation is enhanced by sporting mega events (Frawley \& Cush, 2011; Veal et al., 2012;

MORI, 2004; Pappous, 2011; Sousa-Mast, Reis, Gurgel, \& Duarte, 2013). Arguably this research focuses too much on outcomes (i.e. increased numbers of people participating) and does little to articulate the challenging and complex nature of delivering sport participation legacy (Charlton, 2010), through a complex network of program providers. Likewise, evidence of economic legacy varies across events with some events preceding catastrophic economic loses or minor long term benefits at best (Kasimati \& Dawson, 2009; Zimbalist, 2016).

This relates to how legacy is percieved and the continual expectation that legacy is supposed to generate beneficial outcomes. The term 'legacy' is problematic, presenting a one dimensional view, focusing on positive outcomes, without sufficient consideration of the negative risks (Stewart \& Rayner, 2016). Many studies have examined the attitudes and support of host residents towards mega events, with expected positive legacies often being an important and strongest predictor of support (Gursoy et al., 2017; Scheu \& Preuss, 2018; Vetitnev \& Bobina, 2015). Yet, this underesitmates the complexity of legacy, encouraging the rhetoric that legacy can be a solution to an existing problem, with intangible legacies that contribute to city branding for example, being highly valued and noted by host residents (Thomson et al., 2018).

This leads to the examination of planned, predermined objectives and whether they succeeded or failed, this doesn't encourage investigation into the unexpected, unvalued or unplanned legacy. Even though legacy is a contested concept, which can take multiple forms, focus has largely been placed on discussing positive or mixed legacy outcomes, with significantly less focus on negative legacies within the academic discourse (Thomson et al., 2018). Research examining volunteer legacies for example, responds to the predetermined plan 
to increasing volunteering and investigates the success of a specific programme and outcome achievement. Although interesting insights have been generated into the motives, challenges and likelihood of continued volunteering efforts (Dickson, Benson, \& Terwiel, 2014; Nichols, Ralston, \& Holmes, 2017), little focus has been placed on addressing the specific experiences and charateristics of these individuals (Giannoulakis, Wang, \& Gray, 2007), which is critical to understand if volunteers accept or resist legacy plans and the role that social mechanisms (previous experience in sport, ideologies, class) play.

Only a few studies have investigated the long-term evolution of the volunteering legacy, with Fairley, Gardiner, \& Filo (2016) conducting a study 10 years post the Sydney Olmypics in 2000, examining the informal processes which perpetuated legacy, such as using memorabilia, sharing stories and expertise on the volunteer experience, and forming a volunteer group providing insight into those generative mechanisms. Without this, research often has a narrow and limited understanding of why a volunteering legacy may or may not have been achieved, leaving significant gaps in understanding legacy deliveryand constraining factors.

\subsubsection{Measuring legacy: [How do we know] legacy is real?}

Given that there are a wide variety of types of legacy (from economic, social to environmental and political), we have relied on a wide variety of evidence that these legacies have been produced as a result of a mega sports event. However, our operationalization of legacy primarily as 'outcomes' (e.g. increased number of participants in sport, rise in spending from tourism or increased number of people volunteering in the community) has resulted in a focus on measuring whether the planned legacy objectives have been met, using observable, tangible 
evidence (Baade \& Matheson, 2004; Bauman, Bellew, \& Craig, 2015; Frawley \& Cush, 2011; Moss, Gruben, \& Moss, 2018).

Legacy research has expanded on this slightly by examining different stakeholder interpretations of legacy and whether it has occurred or not (Girginov \& Hills, 2008; Kaplanidou \& Karadakis, 2010; Rocha, 2017; Scheu \& Preuss, 2018), providing greater insight into the perceptions of muiltple actors and the influence that their differing interests and experiences may have. Yet, research in this area is notably limited, with Bocarro, Byers \& Carter (2018) highlighting the need for multiple stakeholder assessments to be examined and compared over a longer time period to understand legacy. Currently, there is little indication how conflicting stakeholder needs are resolved and to whose satisfaction.

Overall, defining and measuring mega sports event legacy has taken a fragmented approach, with studies focusing on individual categories of legacy, measured through observable outcomes, such as evidence of increasing sport participation (Frawley \& Cush, 2011; Hindson, Gidlow, \& Peebles, 1994; Veal et al., 2012) or economic impact (Kasimati \& Dawson, 2009; Zimbalist, 2016). This has been helpful in recognizing the many forms that legacy can take, but as Chappelet (2012) and more recently Bocarro et al. (2018) suggested, research needs to focus on how legacies may be produced, rather than a superficial focus debating the existence of legacy typologies. Considering the process of legacy delivery will enable an understanding to emerge as to why MSEs succeed or fail to produce specific legacies. Some research has begun to suggest that exploring the concept of leveraging may reveal the process of producing legacy (Chalip, 2014) and we discuss this approach in the following section.

\subsection{Legacy delivery}


The concept of leveraging has been suggested as indicative of the process of legacy delivery, but we argue that this focuses narrowly on intentionally designed, formal strategies and mechanisms and does not speak to the intricacies of implementing such strategies across a range of types and sizes of events. Research on the tactical and strategic processes associated with legacy delivery, also known as event leveraging, is in its infancy (Chalip, 2014). This shift is a welcome step towards examining how legacy may be produced, by focusing on strategies aimed at increasing desired outcomes of MSE (Chalip, 2004; O'Brien, 2007; O'Brien \& Chalip, 2007). Similar to the different categorizations of legacy articulated by Preuss $(2004,2007)$, there are many types of leveraging activities that have been explored within the literature (Chalip, 2006; O’Brien, 2007), including social leveraging (Kellett, Hede, \& Chalip, 2008), image leveraging (Grix, 2012) as well as non-mega and medium size event leveraging (Taks, Chalip, \& Green, 2015; Taks, Green, Misener, \& Chalip, 2014).

Bocarro et al. (2018) and then Koenigstorfer et al. (2019) in their recent reviews of mega event legacy concurred that much of the literature surrounding MSEs focuses on the outcomes rather than the processes (leveraging for example). Notable exceptions to this link to sport participation legacy, which will be used as an illustrative example here, as it is one of the most researched legacy types (Thomson et al., 2018). Some studies have specifically aimed to understand the production of sport participation legacy (Chalip et al., 2017, Macrae, 2017; Taks, Green, Misener, \& Chalip, 2018). These studies reveal some of the barriers voluntary sport clubs experience in legacy delivery, including lack of capacity, lack of club visibility at MSEs, and the sustainability of retaining new participants. Leveraging MSEs for sport participation also requires alliances among sport organizations, event organizers and non-sport stakeholders to integrate the event into the marketing mix of sport organizations (Chalip et al., 2017). Yet 
voluntary sport clubs have been noted to lack specific actions to address barriers to leveraging events for increases in sport participation (Taks et al., 2018).

To examine the process of legacy delivery, a framework is needed that can explore the complexity of legacy, from formal strategies and policies to unanticipated mechanisms and different stakeholder views. We now present the wicked problems framework in more detail, before discussing the lens (framework) from a CR perspective. We believe that by changing the rhetoric and examining the problematic nature of legacy, a much-needed critical approach to legacy delivery is provided.

\section{Conceptual approach: Understanding mega sports event legacy as a 'Wicked Problem'}

Wicked problems are complex, intractable, open-ended, unpredictable social challenges such as global warming, drug abuse, natural disasters, safety of nanotechnology, refugee migration, and child protection (Alford \& Head, 2017). More specifically, Rittel and Webber (1973) identified 10 characteristics of wicked problems (Table 1).

\section{Table 1- Characteristics of Wicked Problems related to Legacy}

\begin{tabular}{|l|l|}
\hline \multicolumn{1}{|c|}{ Characteristics of Wicked Problems } & \multicolumn{1}{c|}{ Characteristics of Legacy } \\
\hline $\begin{array}{l}\text { 1. There is no definitive } \\
\text { formulation/definition of a wicked } \\
\text { problem. }\end{array}$ & $\begin{array}{l}\text { Legacy is complex, with a plethora of definitions and } \\
\text { theoritical conceptualization of legacy } \\
\text { (Chappelet, 2012, Preuss 2015) }\end{array}$ \\
\hline $\begin{array}{l}\text { 2. Wicked problems have no definitive } \\
\text { solution. }\end{array}$ & $\begin{array}{l}\text { There is no universally accepted methodology on how to } \\
\text { generate legacy from a MSE. Legacy outcomes that have } \\
\text { been achieved in one context have failed in others, } \\
\text { leading to the need for various, evolving solutions. }\end{array}$ \\
\hline $\begin{array}{l}\text { 3. Solutions to wicked problems are not } \\
\text { true or false, but good or bad. }\end{array}$ & \begin{tabular}{l} 
A legacy can be positive or negative \\
\hline $\begin{array}{l}\text { 4. There is no immediate or ultimate test } \\
\text { of a solution to a wicked problem. }\end{array}$
\end{tabular} \\
$\begin{array}{l}\text { Legacy contains a high degree of complexity and cannot } \\
\text { be proven through one 'ulimate' assessment, as it evolves } \\
\text { over time. }\end{array}$ \\
\hline
\end{tabular}




\begin{tabular}{|l|l|}
\hline $\begin{array}{l}\text { 5. Every (attempted) solution to a } \\
\text { wicked problem is a "one-shot } \\
\text { operation", the results cannot be readily } \\
\text { undone, and there is no opportunity to } \\
\text { learn by trial and error. }\end{array}$ & $\begin{array}{l}\text { Every MSE is a unique 'one-off' event, with high } \\
\text { economic investment, expectations and the } \\
\text { implementation of leveraging strategies to meet a specific } \\
\text { hosting deadine. There is no opportunity to practice. }\end{array}$ \\
\hline $\begin{array}{l}\text { 6. Wicked problems do not have an } \\
\text { enumerable (or an exhaustively } \\
\text { describable) set of potential solutions, } \\
\text { nor is there a well-described set of } \\
\text { permissible operations that may be } \\
\text { incorporated into the plan. }\end{array}$ & $\begin{array}{l}\text { There is no established 'manual' on how to leverage a } \\
\text { MSE. The IOC (2017) is currently working on an } \\
\text { Olympic Legacy Strategy based on past case studies. }\end{array}$ \\
\hline $\begin{array}{l}\text { 7. Every wicked problem is essentially } \\
\text { unique. }\end{array}$ & $\begin{array}{l}\text { Each edition of the Olympic Games and other MSE has it } \\
\text { own specific legacy targets marked by particular geo- } \\
\text { political and cultural characteristics. }\end{array}$ \\
\hline $\begin{array}{l}\text { 8. Every wicked problem can be } \\
\text { considered to be a symptom of another } \\
\text { problem. }\end{array}$ & $\begin{array}{l}\text { Often legacy is used to overcome or accelerate the } \\
\text { achievement of a existing problem. Gentrification is often } \\
\text { an aim of MSE to regenerate an area of poverty and } \\
\text { disadvantage. Yet, in trying to solve this, there are } \\
\text { frequency significant negative impacts and displacement } \\
\text { (Porter, 2009; Watt, 2013). }\end{array}$ \\
\hline $\begin{array}{l}\text { 9. The existence of a discrepancy } \\
\text { representing a wicked problem can be } \\
\text { explained in numerous ways. }\end{array}$ & $\begin{array}{l}\text { Legacy has been viewed and interpreted in multiple ways } \\
\text { due to the diverse stakeholders involved. These variations } \\
\text { and multiple explanations result in differing solutions and } \\
\text { approaches being suggested to achieve legacy. }\end{array}$ \\
\hline $\begin{array}{l}\text { 10. The planner has no "right to be } \\
\text { wrong" (i.e., there is no public tolerance } \\
\text { of experiments that fail)." }\end{array}$ & $\begin{array}{l}\text { The public and mass media have severly critised the } \\
\text { negative intangible legacies of various previous MSE } \\
\text { such as the Montreal 1976, Athens 2004 and Rio 2016 } \\
\text { Olympic Games. }\end{array}$ \\
\hline
\end{tabular}

Table 1 indicates there are benefits and weaknesses to the wicked problem framework.

Wicked problems as a concept draws attention to the complexity of the social world and political processes, but the framework has also been criticized for being prone to totalizing problems, meaning it becomes unclear how to move towards solutions (Lazarusm 2009; Stares, 1996). As we do not solve wicked problems, but rather make progress towards improving them or 
increasing management effectiveness of them (Head, 2010). A framework is needed to facilitate understanding of the component parts of a wicked problem (legacy in this case), to allow the phenomenon to be untangled (Alford \& Head, 2017).

Disentangling problems should reveal that there are different degrees of 'wickedness', resulting in the use of different strategies to tackle them, as opposed to the 'one best way' advocated in early thinking (Alford \& Hughes, 2008). While the literature offers a variety of strategies for dealing with wicked problems (see: Roberts, 2000; Kotter, 1990; Heifetz \& Heifetz, 1994; Durant \& Legge, 2006; Krueter, Rosa, Howze, \& Baldwin, 2004; Termeer, Dewulf, Breeman, \& Stiller, 2015, Weber \& Khademian, 2008), Alford and Head (2017) suggest a two level framework including a typology of wickeness, which we propose is applicable when conceptualizing legacy as a wicked problem and a more finely grained typology of factors (in particular those relevant to the practical needs of decision-makers and managers) underlying the broad categories of wickedness to understand the causal mechanisms that explain the potential solutions (Table 2).

The horizontal axis of the Alford \& Head (2017, p. 402) typology suggests that legacy as a wicked problem may include a range of stakeholders, increasing in diffculty (from indifferent relationships to multiple groups with conflicting values and interests), which leads to relutance (relative power) to share understanding, meaning that the locus of knowledge is fragmented. Yet, in some contexts we have seen examples of multiple stakeholders working together, sharing relevant knowledge and ideas and collaborating in the planning of a MSE (Sport Birmingham, 2018). The degree to which these insights and sugggestions are utilized by policy stakeholders is unclear, due to the relative power they hold. The vertical axis of the typology examines the complexity of the problem and we have seen limited concenus regarding legacy's 
conceptualization, as "neither problem or solution is clear" (Alford \& Head, 2017, p. 402), with legacy seen as a solution to another problem or issue. This means that legacy delivery, including identifying legacy priorities will be different for each MSE and the larger, more complex the event or the 'utopia' surrounding legacy plans, the increasingly 'wicked' an event becomes. If we then consider this in conjunction with the horizontal axis, then the wickedness of a mega sports event legacy can range from very wicked where there is considerable political motivation, large number of divergent interests from stakeholders and problems in communicating a clear message regarding legacy plans and delivery.

From this, it is clear how each wicked problem needs to be considered on a spectrum and dealt with on a case by case basis, as mega sports event legacy can present different degrees of wickedness and strategies and initiatives used to develop legacies may vary according to different event contexts. This is more apparent in stage two (Table 2) which deconstructs the dimensions of wicked problems further.

Table 2 Deconstructing the dimensions of legacy as a wicked problem

\begin{tabular}{|c|c|c|c|}
\hline Basic Dimension & $\begin{array}{c}\text { Causal } \\
\text { Categories }\end{array}$ & More Detail Legacy Dimensions & $\begin{array}{c}\text { Scale of } \\
\text { Wickedness }\end{array}$ \\
\hline \multirow{2}{*}{$\begin{array}{l}\quad \text { Vertical } \\
\text { (Legacy, } \\
\text { challenges/problems } \\
\text { as a result of legacy } \\
\text { planning and } \\
\text { delivery processes) }\end{array}$} & $\begin{array}{l}\text { Inherent } \\
\text { complexity }\end{array}$ & $\begin{array}{l}\text { - Number of legacy priorities } \\
\text { - Nature of problems legacy } \\
\text { attempts to address } \\
\text { - Potential problems resulting } \\
\text { from legacy priorities }\end{array}$ & $\begin{array}{l}\text { Greater number / } \\
\text { complexity of } \\
\text { legacy aims \& } \\
\text { potential problems } \\
\text { then increased } \\
\text { wickedness }\end{array}$ \\
\hline & $\begin{array}{l}\text { Clarity of the } \\
\text { Problems }\end{array}$ & $\begin{array}{l}\text { Hidden agendas / priorities } \\
\text { - Legacy is hard to define, } \\
\text { takes multiple forms }\end{array}$ & $\begin{array}{l}\text { Pre and post event } \\
\text { evidence }\end{array}$ \\
\hline
\end{tabular}




\begin{tabular}{|c|c|c|c|}
\hline & $\begin{array}{l}\text { Clarity of the } \\
\text { Solutions }\end{array}$ & $\begin{array}{l}\text { - Number and complexity of } \\
\text { potential solutions or } \\
\text { consequences evident } \\
\text { - Unexpected outcomes } \\
\text { (positive, negative \& } \\
\text { planned/unplanned) }\end{array}$ & $\begin{array}{l}\text { Level of } \\
\text { contradictions or } \\
\text { unplanned, } \\
\text { negative legacy }\end{array}$ \\
\hline \multirow{4}{*}{$\begin{array}{c}\text { Horizontal } \\
\text { (micro level factors) }\end{array}$} & $\begin{array}{c}\text { Knowledge } \\
\text { (Fragmentation) }\end{array}$ & $\begin{array}{ll} & \text { Institutional fragmentation- } \\
\text { - } & \text { Multiple organisations and } \\
\text { stakeholders involved and } \\
\text { accountable/ responsible }\end{array}$ & $\begin{array}{l}\text { High knowledge } \\
\text { fragmentation }= \\
\text { more wicked }\end{array}$ \\
\hline & $\begin{array}{l}\text { Knowledge } \\
\text { (Framing) }\end{array}$ & $\begin{array}{l}\text { - Varied/limited approaches to } \\
\text { collecting knowledge } \\
\text { - Framed around planned } \\
\text { legacy, leads to missing } \\
\text { knowledge and/ or a distorted } \\
\text { understanding of legacy }\end{array}$ & $\begin{array}{l}\text { Formal knowledge } \\
\text { framing and focus= } \\
\text { increased } \\
\text { wickedness }\end{array}$ \\
\hline & Interests & $\begin{array}{l}\text { - Interest differentiation/conflict } \\
\text { in legacy priorities, aims or } \\
\text { post event legacy } \\
\text { - Diverse values and priorities }\end{array}$ & $\begin{array}{l}\text { More differentiation } \\
=\text { more wicked }\end{array}$ \\
\hline & Power & $\begin{array}{l}\text { Difference between } \\
\text { stakeholders favouring the } \\
\text { mega event \& those } \\
\text { disadvantaged by the event. } \\
\text { - Powerful actors can dominant } \\
\text { legacy discourse }\end{array}$ & $\begin{array}{l}\text { More power } \\
\text { differential = } \\
\text { greater wickedness }\end{array}$ \\
\hline
\end{tabular}

Adapted from: Alford and Head (2017, p. 406).

Legacy as a wicked problem, with various levels of 'wickedness', adds substantially to knowledge in this field, as it moves away from treating all legacy as equally problematic or as the solution to societal and economic issues. Furthermore, the additional causal categories/detailed dimensions indicated as important to understanding the scale of wickedness (Table 2) point to the importance of developing solutions to legacy delivery for each different event. Over time, empirical data could indicate if there are patterns or similarities between mega events. As this is a thorough and detailed conceptualization that provides a different view of 
legacy and the problems it generates, further detail is needed to operationalize this notion and for this, we overlay the Critical Realist ontology, explained in the next setion.

\subsection{Legacy as wicked problems: Critical realist perspective}

Consistent with Byers' (2013) articulation of Critical Realism, applied to understanding control of volunteers, we use Marsh's (1999) six features of Critical Realism and Tsoukas' (1994) notion of multiple levels of reality to operationalize legacy as a wicked problem. Marsh (1999) contends that Critical Realism accepts there is a reality external to individuals (assumption 1) containing both superficial (material and ideal reality) and complex structures (artifactual and social reality) that are not easily or directly observable (assumption 2). Therefore, the legacy process is in part depicted by the formal legacy plans and organization structures produced by host nations and governments, which happens whether various stakeholders in society are aware or not (material layer). This corresponds with the vertical axis of understanding legacy as a wicked problem, the complexity of the problem (legacy seen as potential solution) and the number of variables and clarity of potential solutions.

A person's knowledge of the 'reality' of legacy (how to produce it, their role in production) is limited by their background, attitudes and education and so whether one considers there to be a legacy present depends on their personal characteristics, family influence and social networks. If there is necessity in the world (assumption 3), objects and structures will have causal power. This indicates a need to make causal statements about the determinants or causes of the phenomenon (legacy) to articulate how and why it is produced. However, actors' discursive knowledge regarding 'reality' has a construction effect on the outcomes of social interrelations (assumption 4), which form part of the ideal and artifactual layers of reality depicted in Figure 1. This corresponds to the horizontal dimension of wicked problems, 
specifically noting the knowledge available to decision-makers, degree of fragmentation between individuals and groups. Deeper structures (social reality in Critical Realism ) such as cultures, ideologies, gender, class, race and institutional practices enable and constrain everyday social activities, rather than determine outcomes (assumption 5). For example, a dominant class may bid for and win the right to host a mega sports event, whilst constraining a lower class from resisting the use of public money in this way, instead of influencing its use on alternatives such as housing or health care. Causal mechanisms in social reality are taken for granted and give rise to why material, ideal and artefactual realities exist (assumption 6).

\section{Figure 1- Legacy Delivery as a 'Wicked Problem': A Critical Realist Perspective}

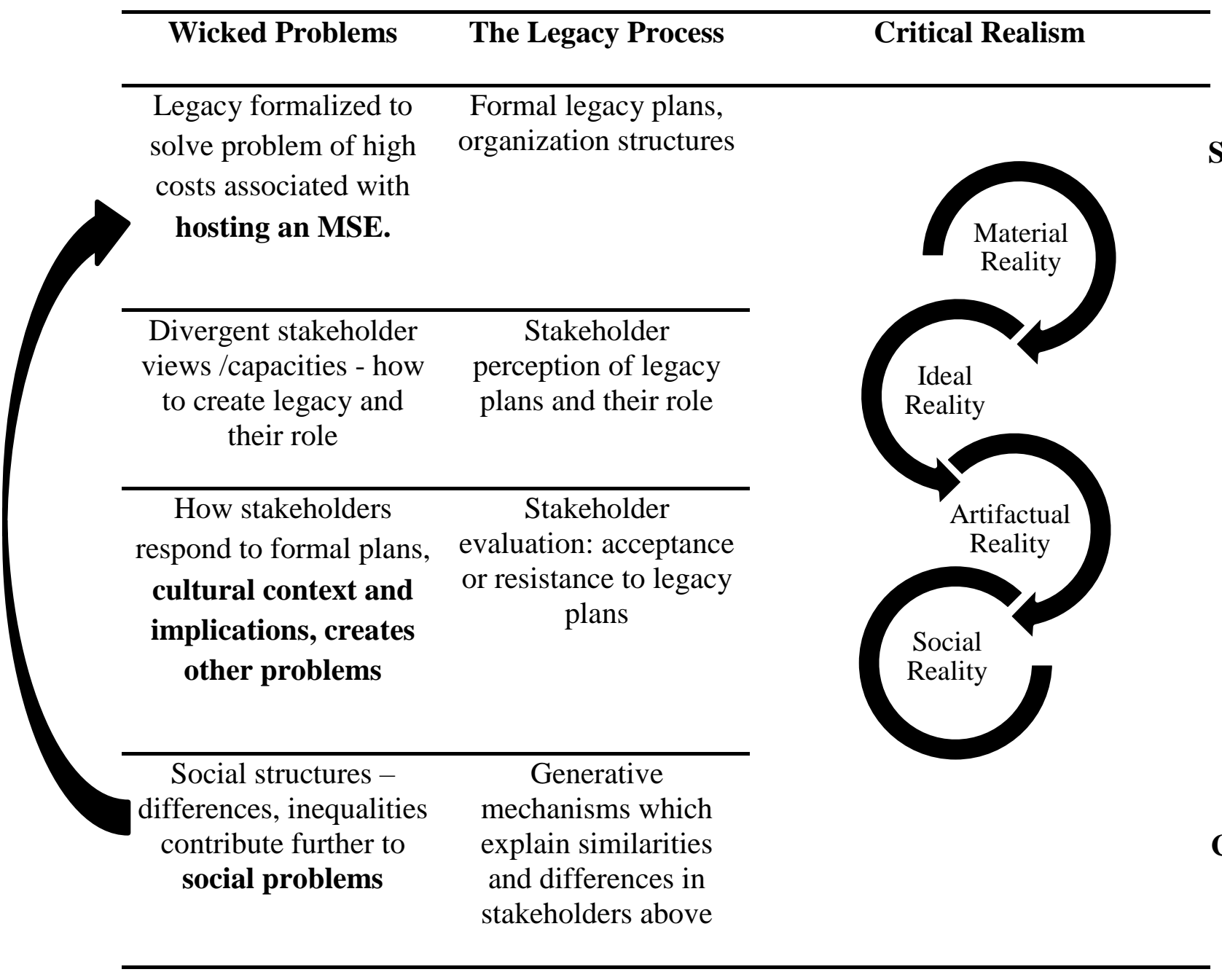


Tsoukas (1994) illustrates that reality can be understood on multiple levels and we apply this ideal (and the 6 assumptions noted above) to the concept of legacy as a wicked problem in Figure 1. The figure illustrates how Wicked Problem's are cyclical, characterized as difficult to define and symptomatic of other problems (to varying degrees). Furthermore, they cannot be solved through a single mechanism and collaboration of multiple stakeholders is required.

Solutions to wicked problems have unintended outcomes and therefore the original problem can often change or evolve, meaning monitoring of both problems, solutions and the relationship between each is necessary.

Wicked problems are hard to define, involve interconnected causal mechanisms and this leads to an ever-evolving problem, which must be re-evaluated. Due to its highly complex nature, wicked problems can appear as a tangled, impenetrable phenomena, which are difficult to research due to their fluid nature. We propose that a critical realist perspective can provide clarity to the chaos, by providing structure in the form of logical steps (four layers). As outlined in Figure 1, this framework gradually increases in depth and complexity, from a more superficial examination of tangible policy documents; through to a deep examination of culture, class and social structures, to understand the generative mechanisms associated to the wicked problem and the stakeholders involved. This corresponds to power, noted in the horizontal dimension of deconstructing wicked problems (Table 2), but adds to that framework by suggesting that the fourth layer of Critical Realism allows for understanding of why stakeholder power and resources enable or constrain the delivery of legacy. The role of deep structures as causal mechanisms has not been considered in the legacy literature to understand delivery, to date.

Cunningham (2013) suggested that the best theories or conceptual advances are ones that help people make sense of the world around them and demonstrate its application to teaching, 
service and practice. To show how a critical realist perspective of legacy as a wicked problem impacts on the real world, both academically and for planners/practitioners, we now provide a discussion of this new conceptualization and its implications.

\section{Discussion and Implications}

Understanding legacy as a wicked problem is a useful and innovative heuristic that adds to the debate on what legacy is and how it may be produced. This section provides further discussion of the process of legacy delivery through the lens of Critical Realism and literature on solutions to wicked problems.

At first glance, superficial structures (Sayer, 2000) (i.e., legacy strategy, leveraging tools, organization infrastructure) may appear to control and produce an event legacy. However, deeper structures (social layer) underlie stakeholders' acceptance and utilization of formal mechanisms (ideal and artifactual layers) (Tsoukas, 1994). These are underpinned by more latent constructs, such as emotion, values, norms, and/or identification with the event (Byers, 2013), or focus of the legacy. Social science involves the study of reflexive agents who may construct, deconstruct and reconstruct structures to understand the deep generative mechanisms, which give rise to the existence of a phenomenon (Sayer, 2000).

Hence, the researcher only partially relies on organization members' perceptions and discursive constructs to understand how legacy (and what type of legacy) is produced and must critically analyze why and how their understanding is generated. Social structures are the "relatively enduring institutionalized relationships between social positions and practices located at distinct levels of analysis that constrain actor's capacities to make a difference" (Reed, 1997, 
p. 35). By understanding how and why stakeholders value or feel oppressed by legacy efforts, it is possible to create potential solutions to the wicked problem of legacy delivery.

Table 3: Applying the Conceptualization of Legacy Delivery to Future MSE Research

\begin{tabular}{|c|c|c|}
\hline CR Layer & $\begin{array}{c}\text { Legacy Delivery as a Wicked } \\
\text { Problem }\end{array}$ & Potential Themes and Questions \\
\hline Material & $\begin{array}{l}\text { Formal legacy plans and tangible } \\
\text { elements; use of media, } \\
\text { organizational structures. }\end{array}$ & $\begin{array}{ll} & \text { Identification of legacy plan } \\
\text { - } & \text { Insight into any formal funding or support } \\
\text { mechanisms } \\
\text { - } \quad \text { Use of Media surrounding an MSE } \\
\text { - } \quad \text { Description of relevant organizational structure } \\
\text { - } \quad \text { What leveraging strategies were outlined/ } \\
\text { created? }\end{array}$ \\
\hline Ideal & $\begin{array}{l}\text { MSE stakeholder perceptions and } \\
\text { capacity regarding their role in } \\
\text { legacy and associated strategies }\end{array}$ & 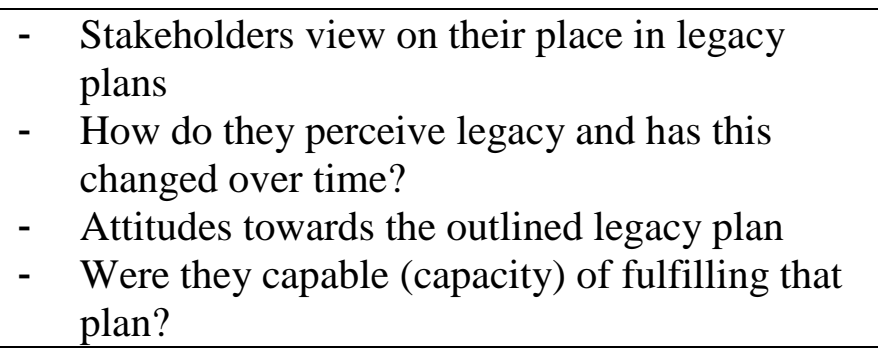 \\
\hline Artifactual & $\begin{array}{l}\text { Acceptance or resistance to legacy } \\
\text { plans, stakeholder's appraisal and } \\
\text { response to formal plans. Creation } \\
\text { of other issues. }\end{array}$ & 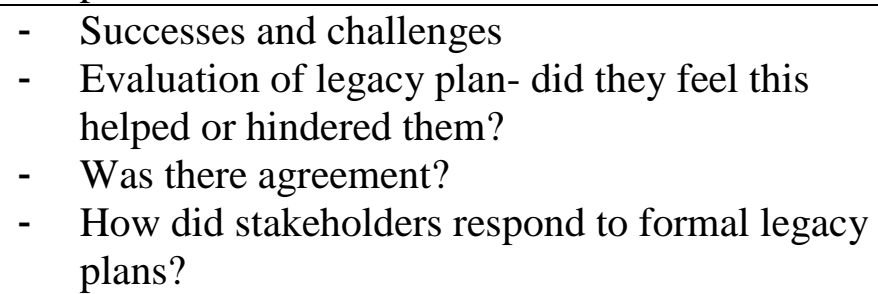 \\
\hline Social & $\begin{array}{l}\text { Cultural mechanisms and social } \\
\text { structures, including disparities } \\
\text { which explain differences in } \\
\text { stakeholder perceptions and actions } \\
\text { above. }\end{array}$ & $\begin{array}{l}\text { Demographic and cultural characteristics - } \\
\text { background, family, age, insights in their } \\
\text { perspective, outlook and cultural values. } \\
\text { - As well as insights into employment, } \\
\text { experiences, attitudes and social networks. }\end{array}$ \\
\hline
\end{tabular}

Table 3 provides an overview of how this conceptualization could be applied to future MSE legacy research, by giving examples of potential themes and questions that could be used and how they relate to the wicked problem and Critical Realist approach. This is not an 
exhaustive list; however, this should provide researchers with key themes that are valuable and required when exploring the multifaceted nature of MSE legacy through this conceptual approach. In the next section, we address how this new conceptualization assists teaching and practice, by providing a discussion of the implications of this new way of thinking.

As legacy is difficult to define, there are uncertainties due to the causal mechanisms involved and objectives which often aim to achieve legacy, this result in additional problems, further complicating legacy delivery. Thus, changing our perspective to view legacy as a wicked problem, combined with the ontological CR perspective we move beyond superficial identification and can understand not only the structures and formal legacy plans (material layer), which provides the context to the legacy. But this conceptualization allows examination of specific stakeholders' perceptions towards legacy (ideal layer) and whether they accept or resist it (artifactual layer), which are all determined and influenced by the social structures (social layer). These generative social mechanisms such as: ideologies, cultural context, race, class and prior experience in sport, generate similarities and differences within the other layers, which ultimately gives rise to the existence or absence of legacy.

As seeing legacy as a wicked problem is consistent with much of the existing literature on legacy which agrees that legacy is complex, consists of multiple types which are interdependent and cannot be planned for nor do they occur in isolation (Preuss, 2018). For example, if government plans for environmental legacy through building additional housing, creating new public spaces and implementing new 'green' policies around an MSE, this may also mean that existing housing (and people's homes) may be displaced, creating negative social legacies for that group. However, it is unknown whether this housing change will lead to positive, negative or a combination of implications for the community and it is difficult to 
pinpoint whether the mega event caused the disruption or was simply the mechanisms by which governments implemented their intended policy in the first place. This new conceptualization of legacy aligns and respects the challenges and unpredictable nature of legacy. Combined with CR perspective this offers a structure through which the complex, interconnected layers of legacy delivery can be explored and understood (See Figure 2).

By understanding legacy as a wicked problem, an opportunity arises for future research to investigate the process of legacy delivery through a context which recognizes its multifaceted and complex nature. The conceptualization outlined in Figure 1 and Table 3, offers a way to investigate, both formal (material level) and informal mechanisms (ideal, artefactual and social levels) that interact over time during legacy planning and delivery. The use of the wicked problem framework within legacy research, also supports Stewart and Rayner's (2016) insightful notion of "uncomfortable knowledge" (p. 157) and the importance of meaningful focus on the negative or dark side of legacy as well as the positive legacies.

We know that legacy is created whether we are aware of it or not, and it is not possible to control for this in its entirety, due to the complexity and intricacy of the multiple stakeholders involved. Legacy is too complex, for one stakeholder group, to decide which legacies and objectives should be planned for and this requires the co-operation of multiple stakeholder groups who are involved in the delivery process. "Collaboration offers one way of recognizing the complexity of problems and engaging the multiplicity of actors affecting the 'wickedness' of a problem" (Head \& Alford, 2015, p. 728).

Legacy, seen often as a positive solution to another problem (achievement wider social outcomes, offsetting hosting costs, infrastructural improvement), and the form it takes, is often 
decided by top level (policy and governmental) stakeholders. These stakeholders create formal mechanisms and structures, to deliver legacy outcomes. This often results in a narrow conceptual focus of scholarly research, which responds to this perspective (investigating the success or failure of a specific pre-planned legacy objective), and largely presents positive legacies (Thomson et al., 2018). Possibly resulting in limited opportunities to identity unanticipated, informal legacies, which may have been created and delivered.

By using a Critical Realist perspective, it is possible to view this wicked problem (legacy) through multiple layers and allows the deeper layers especially 'artifactual' and 'social' to be accounted for (Figure 1), which denote how these stakeholders perceive, observe and respond to legacy. As a result of the conceptualization presented in this paper, we suggest that the current status of research which focuses primarily on different types of legacy, will be further enriched by adopting this new definition to empirically test legacy delivery, as a holistic concept: Mega sports event legacy delivery, as a 'wicked problem' is a product consisting of longterm impacts of various types such as, but not limited to, economic, social, environmental and political, created by a complex process of interaction between multiple layers of reality that include formal and informal mechanisms (material, ideal, artefactual and social) that exist as the result of a mega event in a given context.

The implications of this definition for practice (government, policy makers, host nations) can be understood by viewing legacy as a 'wicked problem' to move the rhetoric away from a predominately positive focus (Stewart \& Rayner, 2016), ensuring that legacy is viewed, planned for, and examined as a complex problem of its own. 
This conceptualization of legacy delivery also tries to address the messy and often impenetrable nature of wicked problems (Lazarusm, 2009). Incorporating the Critical Realist perpective, legacy (as a wicked problem) can been examined through the four layers of reality, from the the formal, superfical (material reality) mechanisms, such as legacy plans, organizational structures and media used and importantly how this is interconnected and influenced by the more complex layers below. As these formal strategies must account for the diverse stakeholder views on how to create legacy and their role (ideal reality) and how individuals respond to and evaluate legacy plans by accepting or resisting them (artefactual reality). These differences and similarities seen within the stakeholders can be understood through generative mechanisms (social reality). As we know the wicked problem increases in difficulty when there are "mulitple parties, conflicting in values/interests" (Alford \& Head, 2017, p. 402).

Our new conceptualization encourages students to think more holistically by recognizing and highlighting the intimately interconnected levels of reality, supporting Miragaia and Soares (2017) point that more critical perspectives in higher education pedagogy in the field of sport management studies are needed. Pedagogically, to apply and utilize critical perspectives would require considerable skills in communication, interpretation and reflection on professional practices accepted within an industry. The need for more critical sport management theory and practice is not new to sport management (see: Frisby, 2005; Shaw \& Frisby, 2006), however, our conceptualization specifically contributes to calls by Zervas and Glazzard (2018) for more critical management studies with pedagogical implication in the field of major sporting events.

\section{Conclusion}


Through recognizing the 'dark side', as well as the (potential) positive light side of legacy, stakeholders can move towards a more realistic, multi-level theory and practice of MSE delivery, thereby realizing greater rewards through addressing those dark and unexplored issues and generative forces. This new perspective of legacy contributes several new insights in to the legacy concept, particularly on the delivery of legacy as a result of MSE. Firstly, legacy is a problematic process and researchers should identify the level of complexity of each event to understand how legacy is delivered and the factors that constrain delivery. Secondly, research should take note of what problems legacy is being used to address and what additional problems or conflicts this generates. Thirdly, stakeholders and decision makers must have a voice in the planning and delivery of legacy, ideally from the bidding stage, so that interests of stakeholders, limitations of knowledge and fragmentation of knowledge can be recognized in a transparent manner. Fourthly, implications of conflicting interests need to be managed and acknowledged as part of the delivery process. Without careful resolution, powerful stakeholders dominate discourses and actions which in turn reinforce suppression of traditionally supressed voices. Finally, enabling and constraining forces such as deep social structures of gender, class, race and institutional norms give rise to explain why power incongruence affects legacy delivery (in planning or post event).

Taken together, these concluding remarks point to the essential role of understanding and managing diversity in legacy delivery. Diverse perspectives give rise to larger knowledge pools, informing planners how to construct legacies that a wider range of stakeholders can identify with. Yet greater diversity may also create increased 'wickedness', conflicts and differences in priorities that will need to be resolved in a transparent format for legacy to be realized. 
Recognition should be given to additional problems generated by the legacy plans, as a solution or the wickedness of a MSE legacy could increase rather than be resolved (for legacy is of varying degrees, a wicked problem).

Drawing on the recent work of Head (2018) related to wicked problems, this new conceptualization helps multiple stakeholders appreciate the complexity and ambiguity of legacy. As, although it is noted that more research is needed to understand how policy successes and failures could be measured in relation to complex wicked problems; this is a step closer to "providing a framework, which could assist practitioners, policy makers and academics to ensure that emphasis is given to the diversity and primacy of stakeholders values and practitioner perspectives" (p. 13). Legacy as a wicked problem, from a Critical Realist perspective, advances our understanding of legacy as it provides deep insight into the process by which legacy may form and be constrained. Considering the legacy process as problematic, through multiple layers of reality, encourages greater attention to how a lack of respect to diverse perspectives (i.e., gender, race, class or other social structures) can give rise to greater wickedness and prevent legacy from forming or encourage negative legacies to evolve. This points to the immense importance of diversity training and empathy development among sport managemet students, as opposed to the largely commercial focus of many sport mangement programs. 


\section{References}

Alford, J.\& Head, B.W. (2017). Wicked and less wicked problems: A typology and contingency framework. Policy and Society, 36(3), 397-413.

Alford, J., \& Hughes, O. (2008). Public value pragmatism as the next phase of public management. The American Review of Public Administration, 38(2), 130-148.

Archer, M., Bhaskar, R., Collier, A., Lawson, T., \& Norrie, A. (1998). Critical Realism: Essential readings, New York: Routledge.

Baade, R. A., \& Matheson, V. A. (2004). The quest for the cup: assessing the economic impact of the world cup. Regional studies, 38(4), 343-354.

Bauman, A., Bellew, B., \& Craig, C. L. (2015). Did the 2000 Sydney Olympics increase physical activity among adult Australians?. Br J Sports Med, 49(4), 243-247.

Bocarro, J., Byers, T., \& Carter, L. (2018). Legacy of sporting and non-sporting mega event research: What next? In Legacies and Mega Events: Fact or Fairy Tale, (pp. 7-24). Routledge: Oxon.

Boykoff, J., \& Fussey, P. (2014). London's shadow legacies: security and activism at the 2012 Olympics. Contemporary Social Science, 9(2), 253-270.

Brittain, I., Bocarro, J., Byers, T., \& Swart, K. (Eds.). (2018). Legacies and Mega Events: Fact or Fairy Tales? Routledge: Oxon. 
Boukas, N., Ziakas, V., \& Boustras, G. (2013). Olympic Legacy and Cultural Tourism: Exploring the Facets of Athens' Olympic Heritage. International Journal of Heritage Studies, 19(2), 203-228.

Brownill, S., Keivani, R., \& Pereira, G. (2013). Olympic legacies and city development strategies in London and Rio; beyond the carnival mask? International Journal of Urban Sustainable Development, 5(2), 111-131.

Byers, T. (2013). Using critical realism: a new perspective on control of volunteers in sport clubs. European Sport Management Quarterly, 13(1), 5-31.

Byers, T. (2018). Trends in professional sport organizations and sport management and their market impact, in Breuer, M. and Forrest, D. (Eds.). The Palgrave Handbook on the Economics of Manipulation in Sport. Switzerland, Palgrave Macmillan.

Cashman, R. (1998). Olympic Legacy in an Olympic City: Monuments, Museums and Memory. Paper presented at the Fourth International Symposium for Olympic Research; Global and Cultural Critique: Problematizing the Olympic Games.

Chalip, L. (2014). From legacy to leverage. Grix, J. (Ed.) Leveraging legacies from sports megaevents: Concepts and cases, (pp. 2-12), London: Palgrave.

Chalip, L. (2006). Towards Social Leverage of Sport Events. Journal of Sport \& Tourism, 11(2), $109-127$.

Chalip, L. (2004). Beyond impact: A general model for sport event leverage. In B. Ritchie \& D. Adair, Sport tourism: Interrelationships, impacts and issues (pp. 226-252). Clevedon, UK: Channel View Publications. 
Chalip, L., Green, B. C., Taks, M., \& Misener, L. (2017). Creating sport participation from sport events: making it happen. International Journal of Sport Policy and Politics, 9(2), 257276.

Chappelet, J.-L. (2008). Olympic environmental concerns as a legacy of the Winter Games. The International Journal of the History of Sport, 25(14), 1884-1902.

Chappelet, J.-L. (2012). Mega Sporting Event Legacies: A Multifaceted Concept. Papeles de Europa, 25, 76.

Charlton, T. (2010). "Grow and Sustain": the role of community sports provision in promoting a participation legacy for the 2012 Olympic Games. International Journal of Sport Policy, 2(3), 347-366.

Cunningham, G. (2013). Theory and theory development in sport management. Sport Management Review, 16: 1-4.

Dickson, T., Benson, A., \& Terwiel, A. (2014). Mega-event volunteers, similar or different? Vancouver 2010 vs London 2012. International Journal of Event and Festival Management, 5(2), 164-179.

Durant, R. F., \& Legge Jr, J. S. (2006). “Wicked problems,” public policy, and administrative theory: Lessons from the GM food regulatory arena. Administration \& Society, 38(3), 309-334.

Fairley, S., Gardiner, S., \& Filo, K. (2016). The spirit lives on: The legacy of volunteering at the Sydney 2000 Olympic Games. Event Management, 20(2), 201-215. 
Frawley, S., \& Cush, A. (2011). Major sport events and participation legacy: The case of the 2003 Rugby World Cup. Managing leisure, 16(1), 65-76.

Frisby, W. (2005). The good, the bad, and the ugly: Critical sport management research. Journal of sport management, 19(1), 1-12.

Gilson, L. L., \& Goldberg, C. B. (2015). Editors' comment: So, what is a conceptual paper? Group and Organization Management, 40, 127-130.

Giannoulakis, C., Wang, C. H., \& Gray, D. (2007). Measuring volunteer motivation in megasporting events. Event Management, 11(4), 191-200.

Girginov, V., \& Hills, L. (2008). A sustainable sports legacy: Creating a link between the London Olympics and sports participation. The international journal of the history of sport, 25(14), 2091-2116.

Giulianotti, R. (2013). Six security legacies of major sporting events. Paper presented at the ICSS.

Gratton, C., \& Preuss, H. (2008). Maximizing Olympic impacts by building up legacies. The International Journal of the History of Sport, 25(14), 1922-1938.

Grix, J. (2013). Sport politics and the Olympics. Political Studies Review, 11(1), 15-25.

Grix, J. (2012). "Image” leveraging and sports mega-events: Germany and the 2006 FIFA World Cup. Journal of Sport \& Tourism, 17(4), 289-312. 
Grix, J., Brannagan, P. M., Wood, H., \& Wynne, C. (2017). State strategies for leveraging sports mega-events: unpacking the concept of 'legacy'. International Journal of Sport Policy and Politics, 9(2), 203-218.

Gursoy, D., Yolal, M., Ribeiro, M. A., \& Netto, P. A. (2017). Impact of trust on local residents' mega-event perceptions and their support. Journal of Travel Research, 56(3), 393-406.

Head, B. W. (2010). How can the public sector resolve complex issues? Strategies for steering, administering and coping. Asia-Pacific journal of business administration, 2(1), 8-16.

Head, B. W. (2018). Forty years of wicked problems literature: forging closer links to policy studies. Policy and Society, 1-18.

Head, B. W., \& Alford, J. (2015). Wicked problems: Implications for public policy and management. Administration \& Society, 47(6), 711-739.

Heifetz, R. A., \& Heifetz, R. (1994). Leadership without easy answers (Vol. 465). Harvard University Press.

Hiller, H. H. (2006). Post-event outcomes and the post-modern turn: The Olympics and urban transformations. European Sport Management Quarterly, 6(4), 317-332.

Hindson, A., Gidlow, B., \& Peebles, C. (1994). The trickledown effect of top-level sport: Myth or reality? A case study of the Olympics. Australian Journal of Leisure and Recreation, $4(1), 16-24$.

IOC (2017). Legacy Strategic Approach: Moving Forward [Online] https://www.olympic.org/ /media/Document\%20Library/OlympicOrg/Documents/Olympi c-Legacy/IOC_Legacy_Strategy_Full_version.pdf?la=en 
Kaplanidou, K., \& Karadakis, K. (2010). Understanding the legacies of a host Olympic city: The case of the 2010 Vancouver Olympic Games. Sport Marketing Quarterly, 19(2), 110-117.

Kasimati, E., \& Dawson, P. (2009). Assessing the impact of the 2004 Olympic Games on the Greek economy: A small macroeconometric model. Economic Modelling, 26(1), 139-146.

Kassens-Noor, E. (2016). From ephemeral planning to permanent urbanism: An urban planning theory of mega-events. Urban Planning, 1(1), 41-54.

Kellett, P., Hede, A. M., \& Chalip, L. (2008). Social policy for sport events: Leveraging (relationships with) teams from other nations for community benefit. European Sport Management Quarterly, 8(2), 101-121.

Knott, B., Allen, D., \& Swart, K. (2012). Stakeholder reflections of the tourism and nationbranding legacy of the 2010 FIFA World Cup for South Africa. African Journal for Physical, Health Education, Recreation and Dance, 1, 115-125.

Koenigstorfer, J., Bocarro, J., Byers, T., Edwards, M., Jones, G., \& Preuss, H. (in review). Mapping Research on Event-Attributed Installations, Consequences, and Stakeholder Evaluations Considered in Empirical Studies on the Legacy of Mega Sporting Events. Leisure Studies, in Review.

Kotter, J. (1990). A force for change: How management differs from leadership. New York: Free Press.

Kreuter, M. W., De Rosa, C., Howze, E. H., \& Baldwin, G. T. (2004). Understanding wicked problems: a key to advancing environmental health promotion. Health education \& behavior, 31(4), 441-454. 
Lazarus, R. J. (2009). Super wicked problems and climate change: Restraining the present to liberate the future. Cornell L. Rev., 94, 1153-1234.

Macrae, E. H. (2017). Delivering Sports Participation Legacies at the Grassroots Level: The Voluntary Sports Clubs of Glasgow 2014. Journal of Sport Management, 31(1), 15-26.

Marsh, D. (1999). Post War British Politics in Perspective. London: Polity Press.

McCartney, G., Thomas, S., Thomson, H., Scott, J., Hamilton, V., Hanlon, P., Morrison, D.S., \& Bond, L. (2010). The health and socioeconomic impacts of major multi-sport events: systematic review (1978-2008). BMJ, 340, c2369.

Miragaia, D. A., \& Soares, J. A. (2017). Higher education in sport management: a systematic review of research topics and trends. Journal of Hospitality, Leisure, Sport \& Tourism Education, 21, 101-116.

Moss, S. E., Gruben, K. H., \& Moss, J. (2018). An empirical test of the Olympic tourism legacy. Journal of Policy Research in Tourism, Leisure and Events, 1-19.

MORI (2004). The sports development impact of the Commonwealth Games 2002: final report. Research Conducted for UK Sport in Greater Manchester, Blackburn, Congleton and Liverpool. London: MORI.

Morner, M., \& Misgeld, M. (2013). Governing wicked problems: The role of self-organizing governance in fostering the problem-solving capabilities of public sector organizations. In Annual Conference of the European Group for Public Administration (EGPA), Edinburgh, 11-13 September. 
Müller, M. (2015). What makes an event a mega-event? Definitions and sizes. Leisure Studies, 34(6), 627-642.

Nichols, G., Ralston, R., \& Holmes, K. (2017). The 2012 Olympic Ambassadors and sustainable tourism legacy. Journal of Sustainable Tourism, 25(11), 1513-1528.

O’Brien, D. (2007). Points of leverage: Maximizing host community benefit from a regional surfing festival. European Sport Management Quarterly, 7(2), 141-165.

O’Brien, D., \& Chalip, L. (2007). Executive training exercise in sport event leverage. International Journal of Culture, Tourism and Hospitality Research, 1(4), 296-304.

Orr, M., \& Jarvis, N. (2018). Blinded by Gold: Toronto Sports Community Ignores Negative Legacies of 2015 Pan Am Games. Event Management, 22(3), 367-378.

Pappous, A. (2011). Do the Olympic Games lead to a sustainable increase in grassroots sport participation? Sustainability and Sport, 81-89.

Parent, M. M. (2016). Stakeholder perceptions on the democratic governance of major sports events. Sport Management Review, 19(4), 402-416.

Porter, L. (2009). Planning displacement: The real legacy of major sporting events. Planning Theory and Practice 10(3), 395-418.

Preuss, H. (2004). The economics of staging the Olympics: a comparison of the Games, 19722008. Cheltenham: Edward Elgar Publishing.

Preuss, H. (2007). The conceptualisation and measurement of mega sport event legacies. Journal of Sport \& Tourism, 12(3-4), 207-228. 
Preuss, H. (2015). A framework for identifying the legacies of a mega sport event. Leisure Studies, 34(6), 643-664.

Preuss, H. (2018). Event legacy framework and measurement. International Journal of Sport Policy and Politics, 1-16. DOI: 10.1080/19406940.2018.1490336

Raco, M. (2004). Whose gold rush? The social legacy of a London Olympics. In: Vigor, A., Mean, M and Tims, C. (Eds) After the gold rush: A sustainable Olympics for London, 3349. London: Institute for Public Policy Research/Demos.

Reed, M. I. (1997). In praise of duality and dualism: Rethinking agency and structure in organizational analysis. Organization Studies, 18(1), 21-42.

Rittel, H. W., \& Webber, M. M. (1973). Dilemmas in a general theory of planning. Policy Sciences, 4(2), 155-169.

Roberts, N. (2000). Wicked problems and network approaches to resolution. International Public Management Review, 1(1), 1-19.

Rocha, C. M. (2017). Rio 2016 Olympic Games and diplomatic legacies. International Journal of Sport Policy and Politics, 9(2), 277-294.

Sam, M. P. (2009). The public management of sport: Wicked problems, challenges and dilemmas. Public Management Review, 11(4), 499-514.

Sayer, A. (2000). Realism and Social Science. London: Sage.

Scheu, A., \& Preuss, H. (2018). Residents' perceptions of mega sport event legacies and impacts. German Journal of Exercise and Sport Research, 48(3), 376-386. 
Searle, G. (2002). Uncertain legacy: Sydney’s Olympic stadiums. European Planning Studies, 10(7), 845-860.

Shaw, S., \& Frisby, W. (2006). Can gender equity be more equitable?: Promoting an alternative frame for sport management research, education, and practice. Journal of Sport Management, 20(4), 483-509.

Smith, A. (2014). Leveraging sport mega-events: new model or convenient justification? Journal of Policy Research in Tourism, Leisure and Events, 6(1), 15-30.

Sousa-Mast, F. R., Reis, A. C., Gurgel, L. A., \& Duarte, A. F. P. (2013). Are cariocas getting ready for the Games? Sport participation and the Rio de Janeiro 2016 Olympic Games. Managing Leisure 18(4), 331-335.

Sport Birmingham (2018). 'There's still time for you to have your say... and help develop the brand for Commonwealth Games' [Online] https://www.sportbirmingham.org/latestnews/2018/10/theres-still-time-for-you-to-have-your-sayand-help-develop-the-brand-forcommonwealth-games

Stares, P. (1996). Global habit: The drug problem in a borderless world. Washington, DC:

Brookings Institution.

Stewart, A. \& Rayner, S. (2016). Planning and mega-event legacies: uncomfortable knowledge for host cities. Planning Perspectives, 31(2): 157-179.

Taks, M., Green, B. C., Misener, L., \& Chalip, L. (2018) "Sport participation from sport events: why it doesn't happen?", Marketing Intelligence \& Planning, 36(2), 185-198. 
Taks, M., Chalip, L., \& Green, B. C. (2015). Impacts and strategic outcomes from non-mega sport events for local communities. European Sport Management Quarterly, 15(1), 1-6.

Taks, M., Green, B. C., Misener, L., \& Chalip, L. (2014). Evaluating sport development outcomes: the case of a medium-sized international sport event. European Sport Management Quarterly, 14(3), 213-237.

Termeer, C., Dewulf, A., Breeman, G., \& Stiller, S. (2015). Governance capabilities for dealing wisely with wicked problems. Administration \& Society, 46, 680-710.

Thomson, A., Cuskelly, G., Toohey, K., Kennelly, M., Burton, P. \& Fredline, L. (2018). Sport event legacy: A systematic quantitative review of literature. Sport Management Review, in press.

Tsoukas, H. (1994). What is management? An outline of a metatheory. British Journal of Management, 5(4), 289-301.

Veal, A. J., Toohey, K., \& Frawley, S. (2012). The sport participation legacy of the Sydney 2000 Olympic Games and other international sporting events hosted in Australia. Journal of Policy Research in Tourism, Leisure and Events, 4(2), 155-184.

Vetitnev, A. M., \& Bobina, N. (2015). Residents' perceptions of the 2014 Sochi Olympic Games. Leisure Studies. https://doi.org/10.1080/02614367. 2015.1105857.

Watt, P. (2013). 'It's not for us' Regeneration, the 2012 Olympics and the gentrification of East London. City, 17(1), 99-118. 
Weber, E. P., \& Khamedian, A. M. (2008). Wicked problems, knowledge challenges, and collaborative capacity builders in network settings. Public Administration Review, 68, 334349.

Weed, M. (2018). Reflections on sport management, politics and claims made for sport. Keynote presentation, European Association of Sport Management conference, Sweden.

Weed, M., Coren, E., Fiore, J., Wellard, I., Chatziefstathiou, D., Mansfield, L., \& Dowse, S. (2015). The Olympic Games and raising sport participation: a systematic review of evidence and an interrogation of policy for a demonstration effect. European Sport Management Quarterly, 15(2), 195-226.

Zervas, K. \& Glazzard, J. (2018). Sport management student as producer: embedding critical management studies in sport through contemporary pedagogy. Sport, Education and Society, 23(9), 928-937.

Zimbalist, A. (2016). Circus Maximus: The economic gamble behind hosting the Olympics and the World Cup. Washington, DC: Brookings Institution Press. 